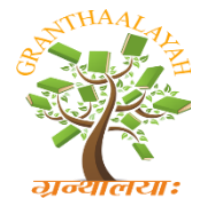

INTERNATIONAL JOURNAL OF RESEARCH GRANTHAALAYAH A knowledge Repository

Management

\title{
INFLUENTIAL MARKETING STRATEGIES ADOPTED BY THE CEMENT INDUSTRIES
}

\author{
Dr. Anjay Kumar Mishra *1 \\ ${ }^{*}$ Associate Professor, Madan Bhandari Memorial Academy Nepal and Pokhara University, \\ Urlabari-3, Morang, Nepal
}

\begin{abstract}
The study is focused to encounter the marketing strategies adopted by cement industries and suppliers. The study is conducted at Madhyapur Thimi Municipality among different level of consumer i.e house owner, supplier, contractor/mason and consultant/engineer. Out of 871 permitted under construction building of fiscal year 2016/17, 89 end consumers and 30 suppliers were selected for questionnaire survey with two different set of questionnaire. Key informant interview was conducted for in depth information while focus group discussion was done to understand influencing strategies.

Bonus coupon and credit period was found to be brand promotional tools among $36.67 \%$ and $23.33 \%$ of the suppliers respectively whereas $50 \%$ of the end consumers get attracted through credit period.

Credit period is the most influential marketing strategy while advertisement being the brand awareness tool to the consumer to set their brand in 'Top of Mind' state.
\end{abstract}

Keywords: Brand Promotions; Sales Tools; Sales Promotions.

Cite This Article: Dr. Anjay Kumar Mishra. (2019). "INFLUENTIAL MARKETING STRATEGIES ADOPTED BY THE CEMENT INDUSTRIES." International Journal of Research - Granthaalayah, 7(10), 155-173. 10.29121/granthaalayah.v7.i10.2019.382.

\section{Introduction}

Cement industry can be considered as oligopoly market as all the industries follow same standards of the government. Thus, the cement offered by the companies remains almost similar with little or no product differentiation. It is used almost in every construction. Although Nepal is not developed country and lots of development activities are going on and the demand of cement is growing day by day for buildings, bridge, and road or hydropower project. Nepalese cement industries are continuously thriving to meet the demand of cement. The Number of brands in cement industry is growing and with increase in number of brands, it is essential to understand how the consumers are attracted to the respective cement brands. To succeed a Manufacturing or organization the product should be liked by the people. Till in Nepal company conform OPC 33 Grade only though 53 grade cement is cost effective in terms of quality, content and rate 
assessment it was further argued that grading of Ordinary Portland Cement should be done. Even it was asked by Mishra and Chaudhary that Inspection of cement in terms of quality should be done so that cement manufacturers could be compelled to maintain their quality.

With these facts, the sales of the cement can vary upon the marketing efforts, like price, brand building, service, media advertisements and the goodwill of the company. Besides that, the strength of the cement is the key factor to influence the consumers.

The study is focused on the study of cement in the current market scenario of Madhyapur Thimi Municipality only. Only private residential buildings that are registered for the construction in the fiscal year 2016/17 was studied for the research. Consumers awareness, perception and behaviour in purchasing Ordinary Portland Cement (OPC) brands that are manufactured only in Nepal are considered in the study. Selection of the consumers are done by random sampling from the total population of registered buildings. Since, the definite data of number of registered suppliers was not available, sampling was done by central limit theorem. According to Mishra and Sharestha (2019) Consumer personality is influenced by risk aversion factor where the consumer seeks to be certain and sure of what they are purchasing. For this, consumer has influence by others characteristics which are consultant, friends and relatives where consultant is considered as the expert and friends/relatives are the prior users of the specific brand. In this way, consumer's decision process is motivated and comes to the point of purchase. Highest consumer choice cement brand is Hetauda cement with $50 \%$ of total consumers followed by Udayapur, Shivam, Maruti and Argakhachi cement which are $23.33 \%, 20 \%, 3.34 \%$ and $3.33 \%$ respectively. Consumers are much focused in the quality and the brand of cement rather than its price as the 2015 earthquake being the major lesson and future threat to the consumer. The medium of quality assurance is found to be consultant, friend and relatives. It is significant that the, years of establishment have played an important role to create the brand image in the consumer to make the decision while purchasing cement, as the highest chosen Hetauda cement is the oldest cement factory amongst other cement brands.

Though, Hetauda cement is perceived as the quality brand by consumer, they are found to be "Shifting Loyal Consumer". Consumer is not committed with the brand as Hetauda cement fails to supply the product with respect to the demand. As a result, consumers make the preference for the second brand in terms of quality, brand image and availability being the major determinants while advertisement and promotional tools being the external driver to aware about the brands.

The study also shows that, though Shivam and Maruti cement are established in two yearse difference period only, $20 \%$ of the consumer have already used Shivam cement while only $3.34 \%$ have used Maruti cement. Since, Shivam cement is doing aggressive advertisement through different media with sales promotional tool in different level from dealer to the end consumer and the availability of cement to meet the demand have resulted to keep in the high preference cement. So the overall objective of the study is to identify the influential marketing strategies adopted by the cement industries. 


\section{Literature Review}

\section{Marketing Strategy and Consumer's Satisfaction}

Marketing strategy is a process of strategically analyzing environmental competitiveness and business factors affecting business units, and forecasting functional trends in business areas of interest to the enterprise (Scrizzi, 2007). In short, it is action plan on how an organization intends to achieve its marketing objectives. Aaker (2008) defined marketing strategy as a process that can allow organization to concentrate resources on optimal opportunities with goals of increasing sales and achieving sustainable competitive advantage. Based on the foregoing statement, it can therefore be said that marketing strategy is an organisation's strategy that combines all of its marketing goals into one comprehensive plan. It involves participating in selling business objectives and formulating corporate and business unit strategies.

Consumer satisfaction is the overall impression of consumer about suppliers and their products or services. Youjae (2010) defined consumer satisfaction as a measure of how products and services supplied by a company meets or surpasses customer's expectation. Consumer satisfaction is a key performance indicator. It shows how prudence a company has used its business unit strategies. In a competitive marketplace where business organisations compete for customers, consumer satisfaction is seen as a key differentiator and increasingly has become a key element of business strategy. Consumer satisfaction provides leading indicator of consumers purchase intention and loyalty. The central focus of consumer satisfaction on the part of the supplier is to narrow the gap between consumers' expectations and perceived performances of the product or service. Farris et.al., (2010) explained that consumer satisfaction is a central concept in modern marketing thought and practice. The concept is emphasizes delivering satisfaction to consumers and obtaining profits in return. Thus, consumer satisfaction is crucial to meeting various needs of consumers, business and society. For any organization, marketing strategies are designed and developed to help the organization meet its objectives. However, if the objectives are to be met, consumer satisfaction must be taken seriously. It is for this reason that marketing strategies are evolved as means to consumers' satisfaction. It should be clarified that marketing strategy is quite different from organisation's corporate strategy. Corporate strategy consists of top management action in deciding the scope and purpose of the business, its objectives, actions and resources necessary to achieve the objectives (Ekinici, 2008).

\section{Types of Marketing Strategies}

Marketing strategies is the action plan which is designed and developed in different ways by different organisations based on their unique environment. In effect, there are more marketing strategies than appear in literature. However, the following are some of the common marketing strategies:

\section{Market Dominance Strategy}

Market dominance strategy strives to put an organization's product or service at the top of other products or services. According to Preston (2012), this strategy is used by organisations to dominate the market. Organisations develop and implement dominance strategy to lead the market or to challenge the market leader with the intention to dominate the leader. Thus, within this strategy, organisations are categorized according to their market share. Kurtz (2012) listed 
companies in this category into four specific areas including leader, followers, challenger and nicher. Accordingly, a leading company controls the largest share of the market of a specific product or service. A market follower on the other hand attempts to imitate products that have the highest market share. Market challenger implement tactics aimed at attacking the market leader and other followers. Market challengers may sometimes uncover market needs not served by the leader or identify shift in the market segment (Preston, 2012).

In Preston (2012) opinion, a firm that adopts market challenging strategy employs offensive marketing strategy while the leader deploys defensive marketing tactic. An offensive marketer may attack opponents rather that its weakness, they match opponents' adverts, price, product, quality and segment - front attack aggressively. They may penetrate into areas where the products of the opponents have not made the right impact - flank attack. They may even bypass competitors through diversification into unrelated products. According to Zila (2012), bypass strategy is the most indirect assault strategy of a market challenger.

While the market challenger may be busy strategizing on how to takeover market share and dominate the market, the market leader concentrates strength using its resources to build an impregnable fortification round its market share. It may even stretch its dominance to new territories through brand proliferation, diversification, customer service and good corporate image through corporate social responsibilities (Aaker, 2008). Companies that fall within market niche strategy are small firms without the requisite skills and resources to compete on equal level with either market leaders or followers. Niche companies identify small market segment which they can satisfy profitably without confronting competitors. Market nichers are likely to engage in lot of research and development in order to discover gaps in the ways opponents allocate resources to satisfy the consumers (Aaker, 2008).

\section{Marketing Mix Strategy}

Marketing mix strategy is a planned mix of the controllable elements of a product's marketing plan commonly termed 4ps - product, price, place and promotion. Chai (2009) explained that marketing mix was offered by McCarthy in 1964 as a conceptual framework that identifies the principal decisions making managers make in configuring their products or services to satisfy consumers' needs. The tools are used to develop long term strategies and short term tactical programmes. Popvic (2006) proposed that a firm adopting marketing mix strategy must create a mix of right product at the right place and sold at the right price using suitable promotions. According to Moller (2006), the definition or justification of 'right' is viewed in the customers' responses to the product or service. To create the right mix therefore, firms have to meet the following conditions according to Popvic (2006): The product has to have the right features, the price must be right, the goods must be at the right place at the right time, and the target group needs to be made aware of the existence of the product through promotions.

\section{Innovative Marketing Strategy}

Innovative marketing strategy is utilized to keep organization on cutting-edge technology and new business practices. Boley (2011) defined innovative marketing strategy as action plan made by an organization to encourage advancement in technology or services by investing in research and development. In Chesbrough and Appleyard (2007), innovative strategies - pioneers early and late 
followers. Today, innovative strategy includes direct mail campaigns, editorial write-ups in newspapers, third party newsletters and out-of-home advertising.

\section{Market Development and Expansion Strategies}

Market development and expansion strategies correspond to what is known in literature as growth strategy. The strategy is centered round company's growth. According to Boyle (2011), it focused on increasing sales in existing market by targeting loyal customers. Information gathered from loyal customers' buying history can help to determine ways in which firms can drive market expansion or growth. Four categories of market expansion strategies have been identified and they include horizontal, vertical integration, diversification and intensification growth strategies. The horizontal integration strives to increase market power, reduce cost of trade, share product resources, and sell more of the same product. Vertical integration helps to reduce transportation costs, grasp upstream and downstream profit margins, and access downstream distribution channels. Diversification consists of internal development of new products, firm acquisition, partnership and new product licensing. Intensification growth strategy penetrates the market to increase customers' loyalty, and creates promising incentives that targets the current customerbased.

\section{Corporate Social Responsibility Strategy}

Corporate social responsibility strategy is used by the companies to strategically build good corporate image for itself. Babalola (2012) defined corporate social responsibilities of firms as market strategy deliberately adopted by firms to promote their image by selling themselves to customers, host communities and staff (stakeholders) through execution of viable projects that do not directly add to profit.

\section{Impact of Marketing Strategies on Consumers' Satisfaction}

The marketing strategies a firm adopts have correlation with customers' satisfaction. However, the direction of the satisfaction depends on how effective the firm has utilized the strategies. Customer satisfaction is the overall essence of the impression about the supplier by the customers. This impression which a customer makes regarding supplier is the sum total of all the processes the customer goes through communicating the supplier before doing any marketing, product manufacturing, quality of products and services and responses to customers' complaints and queries to post delivery services. It therefore behaves on the supplier or marketing firms to choose their strategies carefully so as attract the customers rather than scare them (Shaw, 2012).

\section{Methodology}

\section{Research Approach}

Both qualitative and quantitative analysis was done to get in depth knowledge about the consumer perception towards the cement brand and marketing strategy followed by the cement industries. Qualitative analysis helped to know about the consumers' influencing characteristics through focus group discussion and key informant interview done with Masons, Contractors, Engineers and Architects. Similarly, the study adopted the survey methods by using the quantitative methods of data collection and statistical analysis. This method described customer's perception and acceptability of different brands of cement. This design was selected because it has the advantage 
of describing people attitude and perception towards different brands of cement. It also provides meaningful explanations on people perception.

Sample Size

The total number of registered building for the construction in the fiscal year 2016/17 was 871 .

Thus, the sample size is calculated using the formula as below:

$\mathrm{n}=\mathrm{N} /\left(1+\mathrm{N}^{*}\left(\mathrm{e}^{\wedge} 2\right)\right) \quad($ Yamane, 1967$)$

Where, $\mathrm{n}=$ Sample size

$\mathrm{N}=$ Population

$\mathrm{e}=$ Marginal error

Taking e $=0.1$, Sample size is calculated which is 89 .

Therefore, the sample size for the data collection of the consumer was taken as 89 .

For the sample size of supplier, central limit theorem was used and taken as 30 for the data collection.

\section{Method of Data Collection}

The methodological framework of data collection is illustrated in the figure 3.3 below:

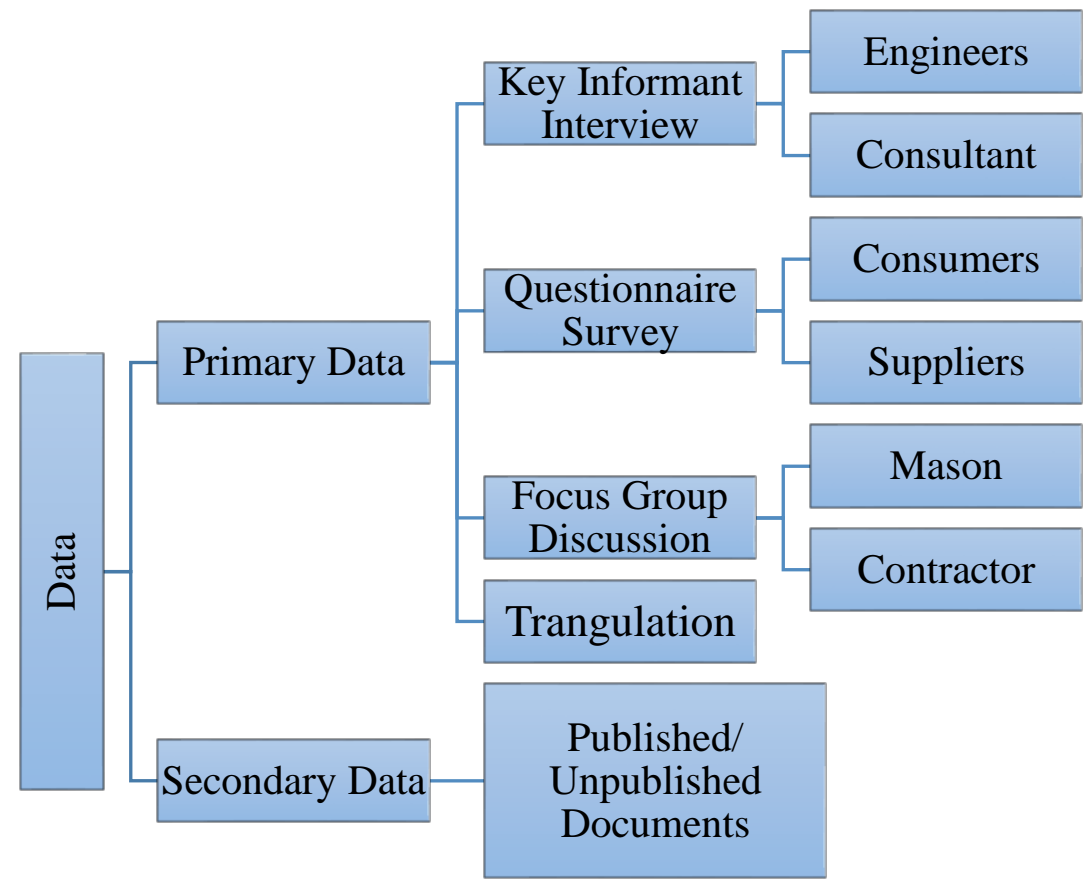

Figure 3.3: Methods of Data Collection

\section{Primary Data}

The primary data was collected from key informant interview, questionnaire survey and focus group discussion. 


\section{Key Informant Interview}

Key Informant Interview was done with Engineers and Architects in Madhyapur Thimi who were involved in the field of building constructions. Through snowball sampling method total number of 5 Architects and Engineers were identified for the interview. They were asked individually about the importance of the promotional tools and the advertisement were discussed during the interview.

\section{Questionnaire Survey}

Questionnaire survey was done with the suppliers and consumers to collect the data involving marketing strategies of cement industries and the consumer behaviour in decision making to purchase the cement brands. Out of 871 consumers registered for the Building Permit in the Fiscal Year 2016/17, questionnaire survey was conducted with 89 sample population of consumer and 30 suppliers registered in Madhyapur Thimi Municipality. Multiple choice questions and Likert five scale point question were prepared separately for both suppliers and consumers. It helped to analyze the consumer behaviour from two perspectives; one from consumer itself and another from the supplier with cross verification of the results.

\section{Focus Group Discussion}

Focus group discussion was done with mason and contractor who were actively involved in the construction of the building of the consumers. It was conducted 4 times with the key topics which were influencing factor to make the choice of that cement, their influence in the consumer.

\section{Secondary Data}

The Secondary data were collected from the published/ unpublished documents, literatures, previous research of consumer behaviours, brand and advertisements.

\section{Data Analysis}

The collected data were analyzed with qualitative as well as quantitative technique. The data collected were entered, classified, tabulated and interpreted accordingly using relative importance factor, mean score and standard deviation. MS- Excel and other computer aided suitable tools are used for the processing, analysis and the presentation of the data collected, and they were logically interpreted with appropriate tables/ charts to find the objectives of the study. Similarly, for the statistical interpretation and analysis, Mean, Standard Deviation, Relative Importance Factor, Rank Correlation and Hypothesis Tess were done which are as follows:

$\operatorname{Mean}(\boldsymbol{\mu})=\quad$ Sum of all variables

Frequency of all variables

Standard Deviation $(\sigma)=\sqrt{\frac{\sum(X-X)^{2}}{n-1}}$

Relative Importance Index $($ RII $)=$ Sum of Weighted Variables

Frequency of all variables 


$$
=\frac{\sum(\mathrm{W} 1 * 5+\mathrm{W} 2 * 4+\mathrm{W} 3 * 3+\mathrm{W} 4 * 2+\mathrm{W} 5 * 1)}{\text { Frequency of all variables }}
$$

DOI: 10.5281/zenodo.3522195

It was applied in the scale point questions to rank the determinants asked to the consumers which helped to differentiate them in the order of highest to the lowest.

$$
\begin{aligned}
& \text { Rank Correlation }(\mathbf{r})=1-\quad \frac{6 \sum \mathrm{d}^{2}}{\mathrm{n}\left(\mathrm{n}^{2}-1\right)} \\
& \text { Where } \mathrm{n}=\text { Total number of variables }
\end{aligned}
$$

$\mathrm{d}=$ difference between two ranks

Rank Correlation was used to find the correlation between Consumers and Supplier in the purchasing behaviour of cement brand with respect to the advertisement and brand of cement.

\section{Summary of Methodology}

\begin{tabular}{|c|c|c|}
\hline $\begin{array}{c}\text { To identify the influential } \\
\text { marketing strategies } \\
\text { adopted by the cement } \\
\text { industries. }\end{array}$ & $\begin{array}{c}\text { Questionnaire survey from consumers } \\
\text { and suppliers, interview with key } \\
\text { informants and group discussions with } \\
\text { mason and contractor }\end{array}$ & $\begin{array}{c}\text { Statistical analysis of } \\
\text { questionnaire survey, } \\
\text { KII and FGD }\end{array}$ \\
\hline
\end{tabular}

\section{Marketing Strategy}

Several cement industries have their own marketing strategy to maximize their sales and to create the brand image among the consumer. During the study, it was found that marketing strategy have huge impact in the consumer to change the behaviour of the consumer and help to build the brand image and the existence in the market. It is found that the government undertaking cement industry has the strategy of continuation of its brand image by giving the quality product. Likewise, other cement industries from the private sector are marketing their brand as a quality product with advertisements, promotional tools and price efficiency.

\section{Brand Preference}

During the study, consumers were asked about their preference of other existing brand with different determinants which results are shown in the table 4.4 below:

Table Error! No text of specified style in document.. 1: Preference of another brand

\begin{tabular}{|l|l|l|l|l|l|l|}
\hline $\begin{array}{c}\text { Preference of other } \\
\text { brand }\end{array}$ & $\begin{array}{c}\text { Relative } \\
\text { Importance } \\
\text { Index (RII) }\end{array}$ & $\begin{array}{c}\text { Strongly } \\
\text { Disagree (1) }\end{array}$ & $\begin{array}{c}\text { Disagree } \\
\mathbf{( 2 )}\end{array}$ & $\begin{array}{c}\text { Neutral } \\
\mathbf{( 3 )}\end{array}$ & $\begin{array}{c}\text { Agree } \\
\mathbf{( 4 )}\end{array}$ & $\begin{array}{c}\text { Strongly } \\
\text { Agree (5) }\end{array}$ \\
\hline Quality & $\mathbf{4 . 4 0}$ & 0.00 & 13.33 & 3.33 & 13.33 & 70.00 \\
\hline Brand image & 4.30 & 0.00 & 3.33 & 10.00 & 40.00 & 46.67 \\
\hline Availability & 4.13 & 0.00 & 6.67 & 10.00 & 46.67 & 36.67 \\
\hline Advertising of Brand & $\mathbf{3 . 5 7}$ & 3.33 & 16.67 & 30.00 & 20.00 & 30.00 \\
\hline Discount sales & 3.37 & 3.33 & 23.33 & 23.33 & 33.33 & 16.67 \\
\hline Promotions of the brand & 3.17 & 6.67 & 23.33 & 36.67 & 13.33 & 20.00 \\
\hline Desire to try new brand & 2.63 & 13.33 & 40.00 & 23.33 & 16.67 & 6.67 \\
\hline
\end{tabular}


Likert scale was used to analyze the consumers' perception on the several determinants as mentioned in the table where Quality is ranked as the most considered factor for the preference of cement brand followed by Brand image and Availability with RII of 4.40, 4.30 and 4.13 respectively. Similarly, RII of Advertisement, Discount sales and the Promotions of the brand as a marketing tools were 3.57,3.37 and 3.17 respectively while consumers don't make their preference to purchase the cement brand with the desire to try new brand. It shows that during the selection of specific brands, advertisement as a marketing tool plays an important role with respect to other strategies followed by quality confirmation and brand image upon its availability in the market. As outlined in literature section 2.9.4, the perception of superiority of the brand is developed in the consumer as cement is the product which have little or no product differentiation. Thus, cement is rather considered as the brand than the product as it has added the value to differentiate it from a product as outlined in literature section 2.9.

\section{Sales Promotion Tools}

From the manufacturer perspective, the main objective is to maximize their sales. For this, several sales promotion tools are found to be adopted by the manufacturer to the supplier and supplier to the end consumer as the chain of distribution.

\section{Sales promotion tools received by Suppliers}

Sales of the cement is distributed by the systemize distribution chain from manufacturer to dealer and dealer to retailers and to the end consumers. Thus, the marketing strategy are applied by different parties from their level to maximize the sales volume.

The study was conducted to know about the marketing strategy adopted by the manufacturer as the top most chain of the distribution while consumer being the end chain of the supply chain. It was found that $36.67 \%$ received the bonus coupons as the sales promotion tools while $23.33 \%$ received the credit period. Similarly, $20 \%$ of each respondent received free calendar/ diaries/ pens and tour offer as the promotional tool to maximize the sales volume. These tools are used as the medium to maximize the sales of the manufacturers where suppliers are used as the influencing factor to change the behaviour of the end consumers.

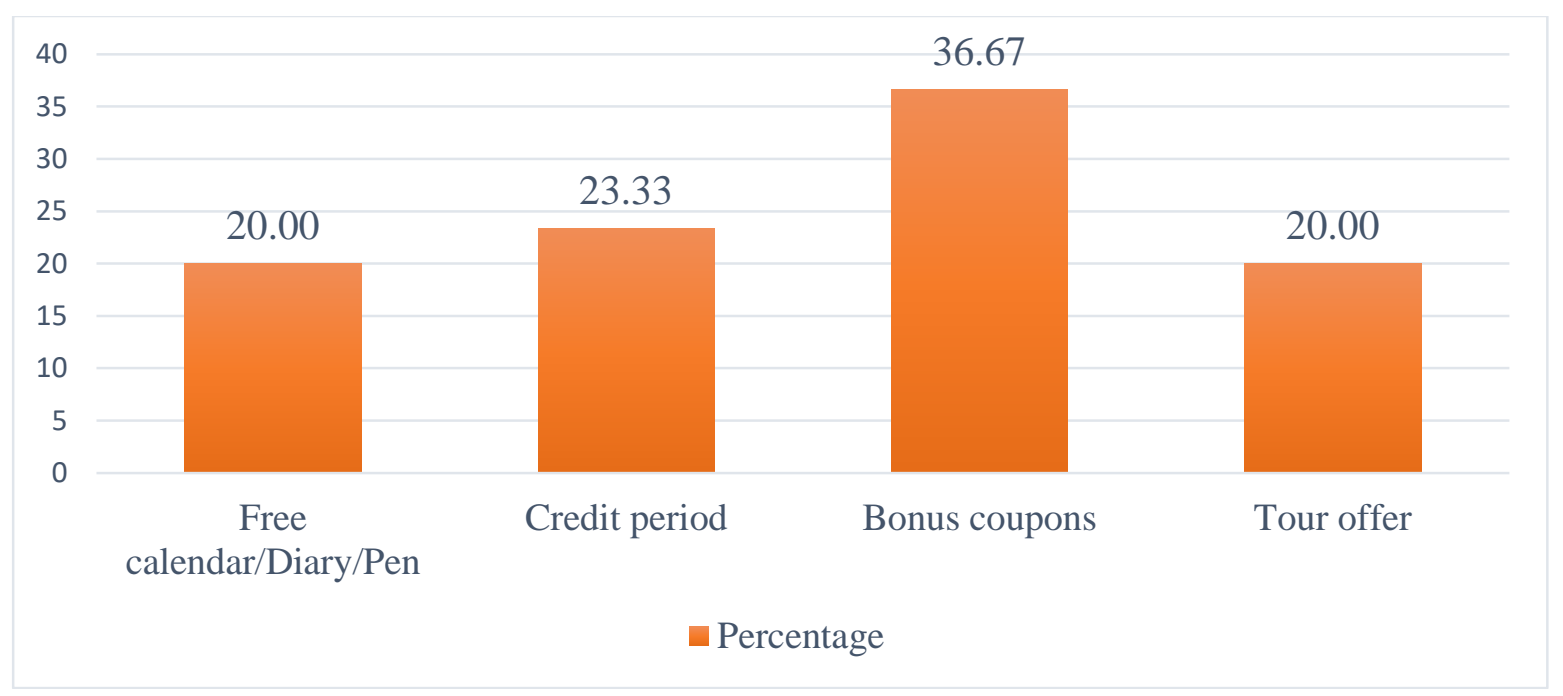

Figure 4.5: Sales promotion tools received by Suppliers 
Similarly, $76.67 \%$ of the supplier received 30 -day credit period while $13.33 \%$ and $10 \%$ of supplier received it for 60 days and 15 days respectively.

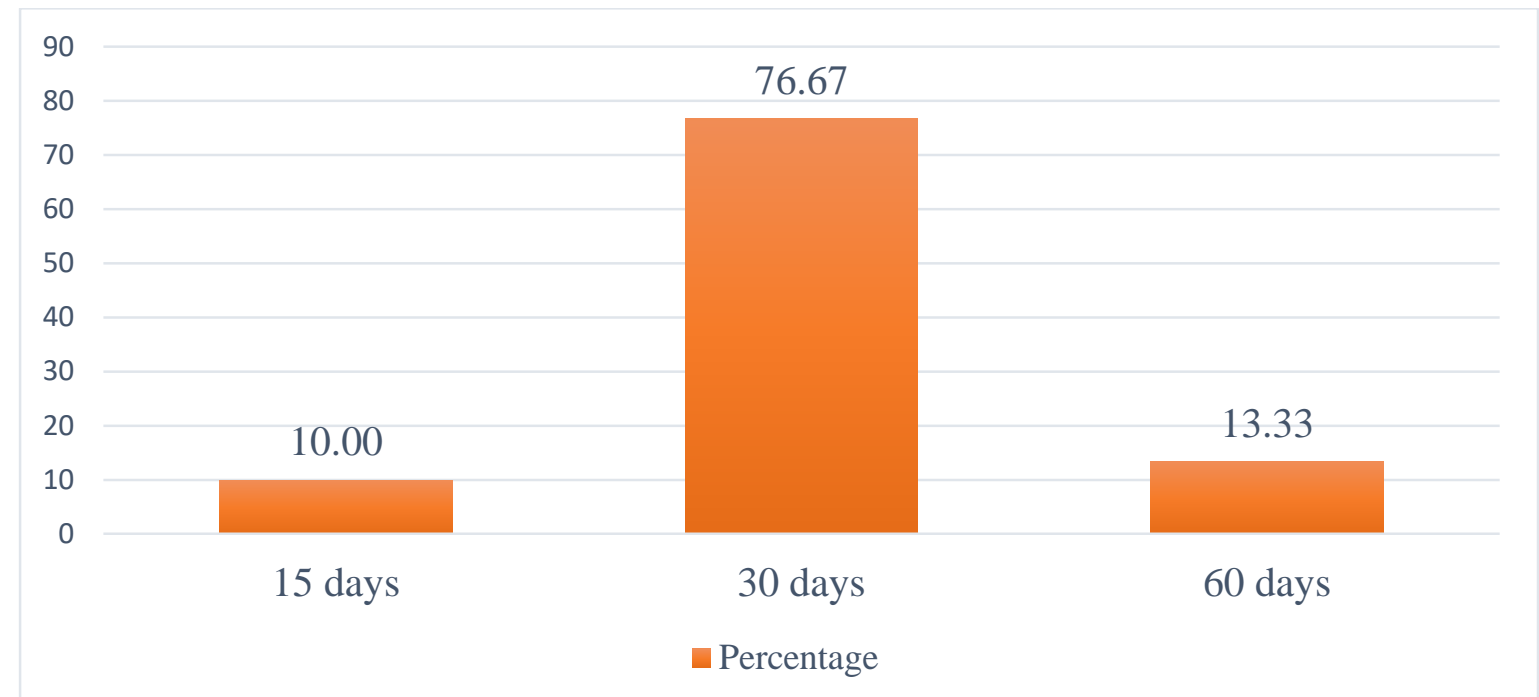

Figure Error! No text of specified style in document..1: Credit period received by suppliers

\section{Sales promotion tools received by Consumers}

Consumers were asked about the sales promotion they have received during the purchase of the cement in which $50 \%$ of the total respondents have received credit period among them, $53.33 \%$ of them received it for one week. Also, $26.67 \%$ of respondent said that they didn't received anything while purchasing cement. During KII and FGD, Hetauda and Udayapur cement were concluded as the cement for which the consumers have to make the instant payment due to high demand of those cements.

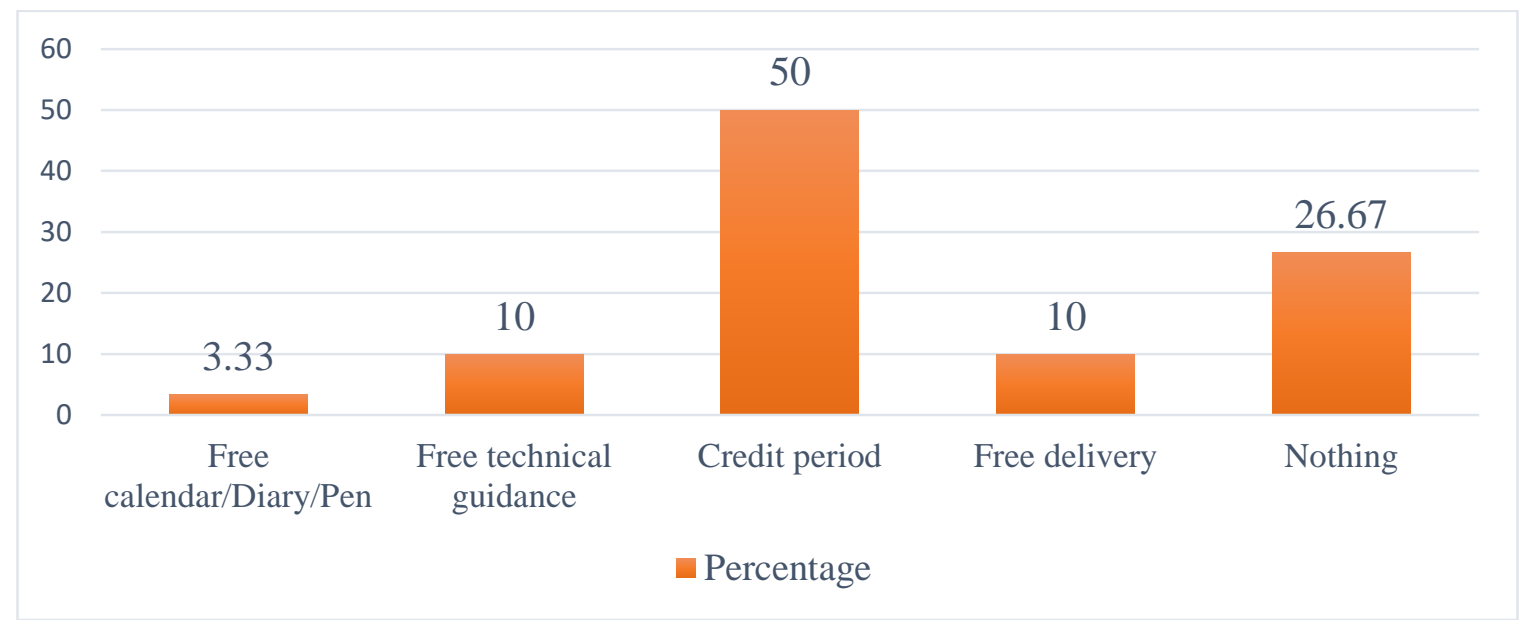

Figure 4.7: Sales promotion tools received by consumers

The study shows that credit period is the highest trending tool to sell the cement brands as $76.67 \%$ of suppliers get 30-day credit period and they sell the consumer with one-week credit period as tabulated in the figure 4.6 and 4.8 . 


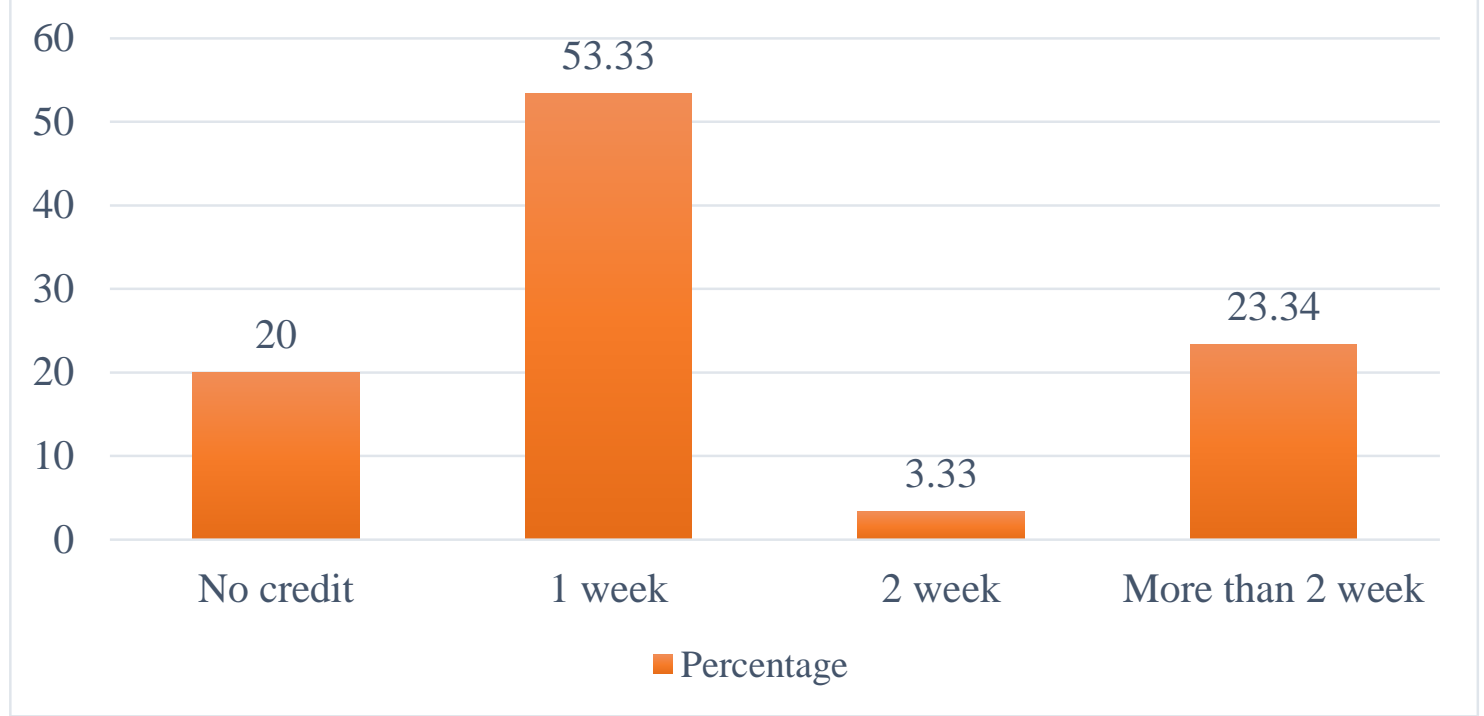

Figure 4.8: Credit period received by consumers

\section{Marketing Strategy Adopted by Manufacturers}

Field survey was conducted to find the sales promotion tools adopted by manufacturers of the cement brands selected by consumers. The slogan, credit period, promotional tools and the medium of advertisement was studied during the research which shows that neither of Hetauda and Udayapur had any slogans nor the promotional tools to attract the consumers while other brands are found to be using different strategies to attract them. Also, both Hetauda and Udayapur didn't facilitate the suppliers and consumers with credit period. Shivam, Maruti and Argakhanchi cement were found to be using their own slogan, credit period, promotional tool and were active in the advertisement through television and hoarding boards as the key medium. In the same time, the advertisement of Hetauda cement were found from the medium of Radio while Udayapur didn't advertise their brand.

Based on Annexure I, manufacturers were found to focused on the confirmation of quality while consultation and bonus coupon were used as promotional tool by the brands. Manufacturers are using advertisement as awareness and communication tools to convince their consumer as per the consumers' preference of quality, bonus coupons and consultant opinions. Among all the available brand of cement, Shivam cement was found to be advertising aggressively which may be due to its high production capacity.

Table 4.5 shows the strategies adopted by those brands.

Table Error! No text of specified style in document..2: Marketing Strategy of Cement Brands

\begin{tabular}{|l|l|l|l|l|l|l|}
\hline S. No. & \multicolumn{1}{|c|}{$\begin{array}{c}\text { Marketing } \\
\text { Strategy }\end{array}$} & Hetauda & Udayapur & \multicolumn{1}{|c|}{ Shivam } & \multicolumn{1}{|c|}{ Maruti } & \multicolumn{1}{|c|}{ Argakhanchi } \\
\hline 1 & Slogan & - & - & $\begin{array}{l}\text { a. Shuvarambha, Atut } \\
\text { Biswash Ko } \\
\text { b. Quality Ko } \\
\text { Maamala Ma NO } \\
\text { COMPROMISE }\end{array}$ & $\begin{array}{l}\text { Haami } \\
\text { Banaudai } \\
\text { Chhau Nepal } \\
\text { Lai }\end{array}$ & $\begin{array}{l}\text { Sabai Vanda } \\
\text { Istariya Cement, } \\
\text { Sabailai Thaha } \\
\text { Cha }\end{array}$ \\
& & & & & \\
\hline
\end{tabular}




\begin{tabular}{|l|l|l|l|l|l|l|}
\hline & & & & $\begin{array}{l}\text { a. Commencement } \\
\text { with Unbreakable } \\
\text { Trust } \\
\text { b. No compromise } \\
\text { when it comes to } \\
\text { quality }\end{array}$ & $\begin{array}{l}\text { Strength to } \\
\text { Build the } \\
\text { Nation }\end{array}$ & $\begin{array}{l}\text { Top Level } \\
\text { Cement, } \\
\text { Everybody } \\
\text { Knows }\end{array}$ \\
\hline 2 & Credit period & No Credit & No Credit & 30 days/7 days & 30 days/7 days & 30 days/7 days \\
\hline 3 & Promotional tool & N/A & N/A & $\begin{array}{l}\text { Construction Expert } \\
\text { Consultation, 1 Bag } \\
\text { free upon purchase of } \\
\text { 20 Bags }\end{array}$ & $\begin{array}{l}\text { Scratch Coupon } \\
\text { upon purchase } \\
\text { of 20 Bags }\end{array}$ & Discount Sales \\
\hline 4 & $\begin{array}{l}\text { Active medium } \\
\text { of advertisement }\end{array}$ & Radio & - & $\begin{array}{l}\text { Television, Hoarding } \\
\text { Boards }\end{array}$ & $\begin{array}{l}\text { Television, } \\
\text { Hoarding } \\
\text { Boards }\end{array}$ & Hoarding Boards \\
\hline
\end{tabular}

\section{Advertisement}

Advertisement is another important marketing strategy that has been followed by almost all the cement industries. It was found that advertisement is the main influencer from the marketers to the consumer with RII of 3.57 as mentioned in table 4.4. Thus, the study of effect of advertisement on the consumer and supplier were conducted to know their behaviour in decision making to purchase the specific cement brands. Different variables related to the advertisement were asked during the survey to find their significance in the consumer behaviour in purchasing the cement brands

\section{Rank Correlation Between Consumer and Supplier}

Both the supplier and the end consumer were asked about the importance of advertisement, determinants related with advertisement and the brand image to analyze the purchasing behaviour of cement brands. Results were then analyzed using Rank Correlation formula to know the correlation between Consumers and Suppliers in purchasing behaviour with respect to the determinants of advertisement and brand.

Table Error! No text of specified style in document..3: Advertisement and Brand in Purchasing Behaviour

\begin{tabular}{|l|l|l|l|l|l|l|}
\hline Advertisement and Brand in purchasing behaviour & \multicolumn{3}{|c|}{ Consumers } & \multicolumn{3}{|c|}{ Suppliers } \\
\cline { 2 - 7 } & MS & $\begin{array}{c}\text { Std } \\
\text { Dev. }\end{array}$ & Rank & MS & $\begin{array}{c}\text { Std } \\
\text { Dev. }\end{array}$ & Rank \\
\hline $\begin{array}{l}\text { Years of establishment is the important factor for the } \\
\text { brand image }\end{array}$ & 4.6 & 0.71 & 1 & 4.6 & 0.89 & 4 \\
\hline $\begin{array}{l}\text { Cement advertisement influences me to change my } \\
\text { preference to buy the cement accordingly }\end{array}$ & 4.4 & 0.81 & 2 & 4.4 & 0.84 & 1 \\
\hline Brand image is important factor to buy/sell the cement & 4.2 & 0.55 & 3 & 4.4 & 0.55 & 6 \\
\hline $\begin{array}{l}\text { Cement advertisements are important factor to } \\
\text { recognize and know about any cement brands }\end{array}$ & 4.17 & 0.91 & 4 & 4.2 & 0.84 & 2 \\
\hline $\begin{array}{l}\text { You take risk to buy new brands in the market just by } \\
\text { adopting the promotions }\end{array}$ & 3.77 & 0.73 & 5 & 4.2 & 0.45 & 5 \\
\hline $\begin{array}{l}\text { Frequency of cement advertisement are important } \\
\text { factor to influence your decision. }\end{array}$ & 3.07 & 1.05 & 6 & 4 & 0.71 & 3 \\
\hline $\begin{array}{l}\text { Importance of celebrities used by companies in brand } \\
\text { promotion. }\end{array}$ & 3 & 1.29 & 7 & 4 & 0.71 & 7 \\
\hline
\end{tabular}


\begin{tabular}{|l|l|l} 
Creativity in cement advertisement effects my decision. & 2.97 & 1
\end{tabular}

It was found that years of establishment is the important factor for the brand image from the consumers' perspective while from the suppliers' perspective cement advertisement is considered as the main determinant that changes their preference to buy the cement. As discussed in the literature section 2.9, brand image is developed through the experience which helped to create consumers' sensitivity and emotional attachment with the brand. Similarly, advertisement has helped to make familiarize with a brand and make the preference of the cement brand during the selection process as it is considered as the medium of brand recognition, brand recall and to set the brand in the top of mind state. Likewise, other determinants; risk of buying new brands adopting the promotions, frequency of cement advertisement, importance of celebrities and creativity of advertisements was calculated in the lower most order of the ranking.

Table 4.5 shows the mean score and standard deviation of different determinants asked during the survey which are ranked in the descending order. Based on the mean score of consumer, ranking was done from 1 to 8 . Similarly, the results obtained from the suppliers are tabulated in the same manner and are ranked with respect to the results of consumer to know the correlation between them.

Table Error! No text of specified style in document..4: Rank Correlation between Consumer and Supplier

\begin{tabular}{|l|l|l|c|}
\hline \multicolumn{4}{|c|}{ Rank Correlation } \\
\hline End Consumer (Rank 1) & Supplier (Rank 2) & d(Rank Difference) & $\boldsymbol{d}^{2}$ \\
\hline 1 & 4 & -3 & 9 \\
\hline 2 & 1 & 1 & 1 \\
\hline 3 & 6 & -3 & 9 \\
\hline 4 & 2 & 2 & 4 \\
\hline 5 & 5 & 0 & 0 \\
\hline 6 & 5 & 3 & 9 \\
\hline 7 & 3 & 0 & 0 \\
\hline 8 & 7 & 0 & 0 \\
\hline & 8 & Sum of $d^{2}$ & 32 \\
\cline { 3 - 5 }
\end{tabular}

Calculating the values from the table, Rank Correlation was found to be 0.619. Since the coefficient is greater than 0.5 , it can be concluded according to the Cohen (1998), they have large correlation in the purchasing behaviour of cement brands with respect to advertisement and brand. It means that the perspective of the consumer and supplier with the brand image and the advertisement is closely related.

\section{Level of Attention for Advertisement}

Level of attention in the consumer when they see new advertisement in different medium was asked during the survey. It was found that $46.67 \%$ of total respondent pays little attention when they see new advertisement of cement. $23.33 \%$ of total respondent pays more attention, $26.67 \%$ pays some attention to the new advertisement while very small number of consumer ignore the advertisement which was found to be $3.33 \%$ which were in the age group of 51-61 years. 


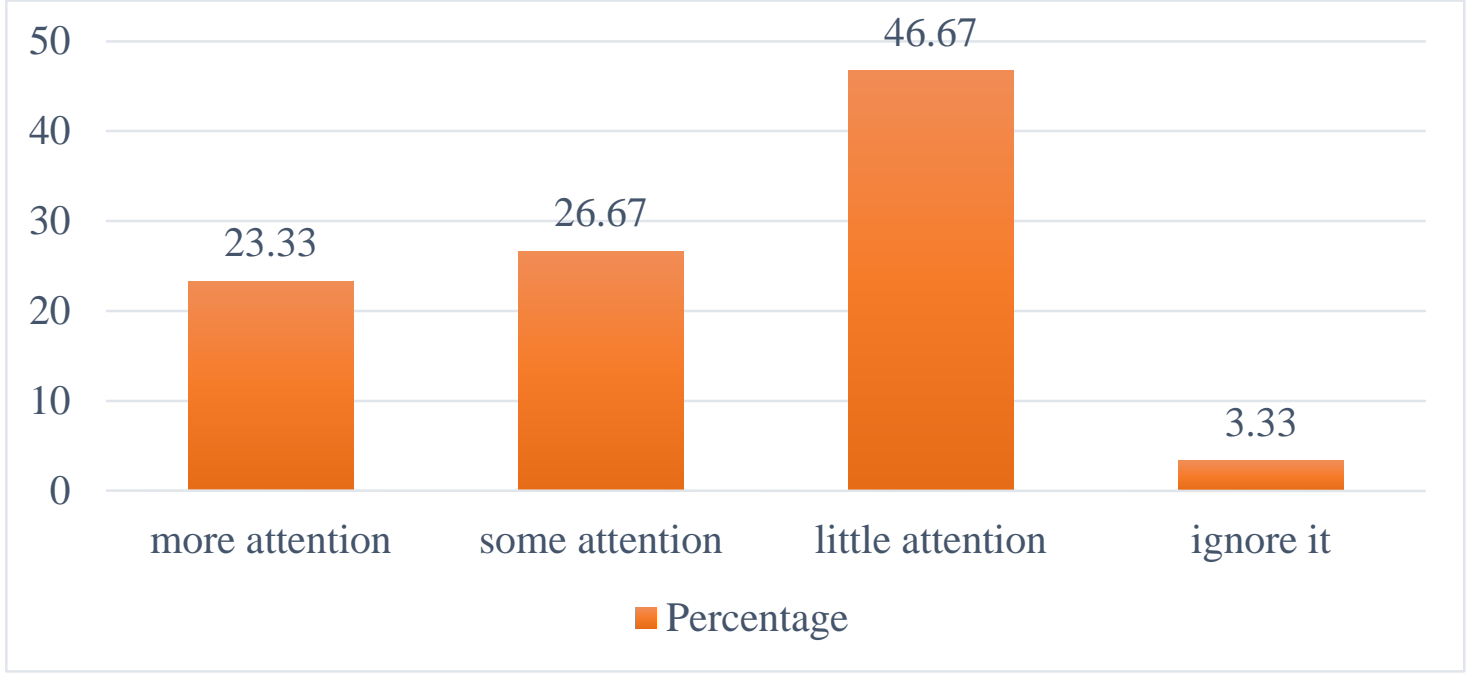

Figure 4.9: Level of attention for advertisement

\section{Medium of Advertisement}

Out of 89 sample population, 39 gets attention from the television which is $43.33 \%$ of total respondents. Consumer who gets attention via Newspaper, Word of mouth and Hoarding boards are $23.33 \%, 20 \%$ and $13.33 \%$ respectively. It shows that the radio does not grab the attention of consumer. Similarly, the result of socio-demographic characteristics shows that majority of consumers of the age group of 29-39 years and 40-50 years have selected television as the medium of attention which was $16.67 \%$. Similarly, the $26.67 \%$ of consumers involved in the Business as an occupation and with the family income of 50 Thousand-1Lakhs respectively gets attention by television.

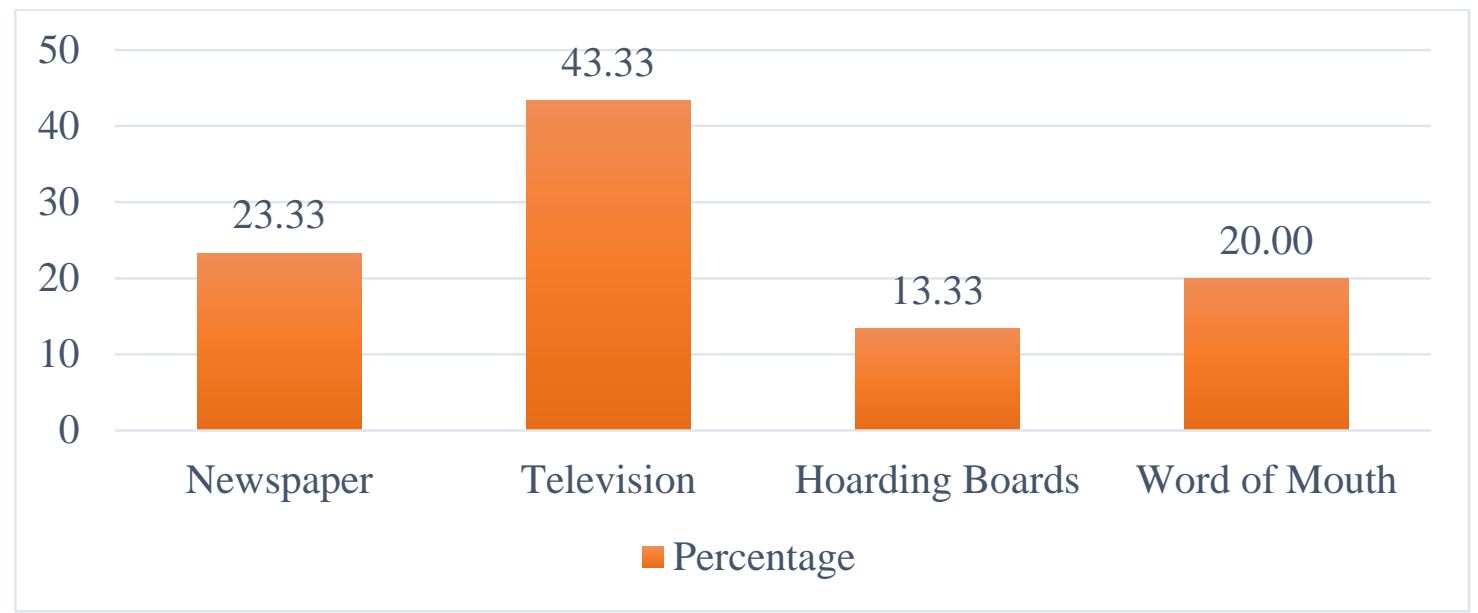

Figure Error! No text of specified style in document..2: Medium of advertisement

\section{Effect of Advertisement}

As discussed in the literature section 2.8, advertisement is the way of creating awareness to the consumer about the brands and creating the brand image in the consumer. The study on its effect on the consumer shows that $43.33 \%$ have positive impression on the specific brand when they see the advertisement of that cement. It is also found that 21 consumers out of 89 sample population 
have helped for the decision process to purchase the cement which is $23.33 \%$ while $10 \%$, and $18 \%$ of total respondents have the tendency of recall and interest in the cement brand respectively. While 2 out of 89 sample population were neutral with the advertisement and have no effect.

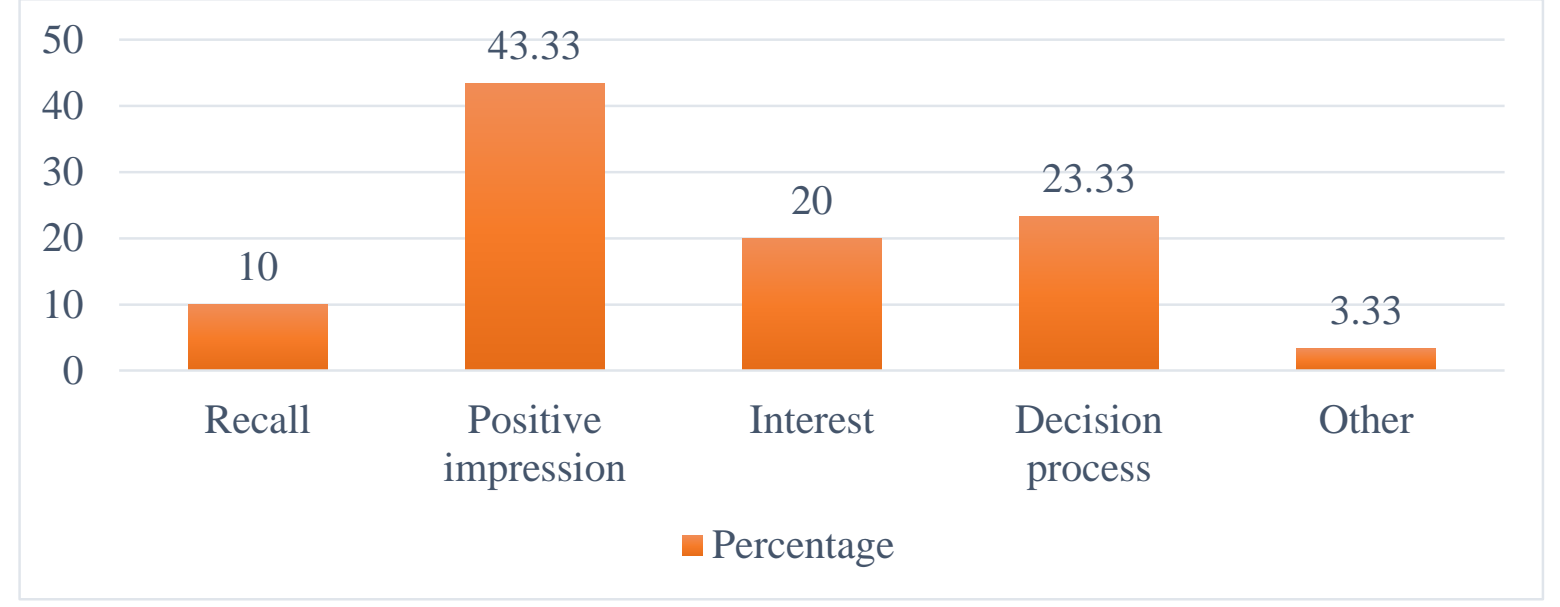

Figure Error! No text of specified style in document..3: Effect of advertisement

\section{Input of Advertisement last on the Consumer}

Figure 4.12 shows that its input is very deviated among the consumers as $36.67 \%$ have one month of awareness while it lasts for few hours for $33.33 \%$ of consumer. Similarly, $20 \%$ and $10 \%$ of consumers have its input for one day and one week respectively.

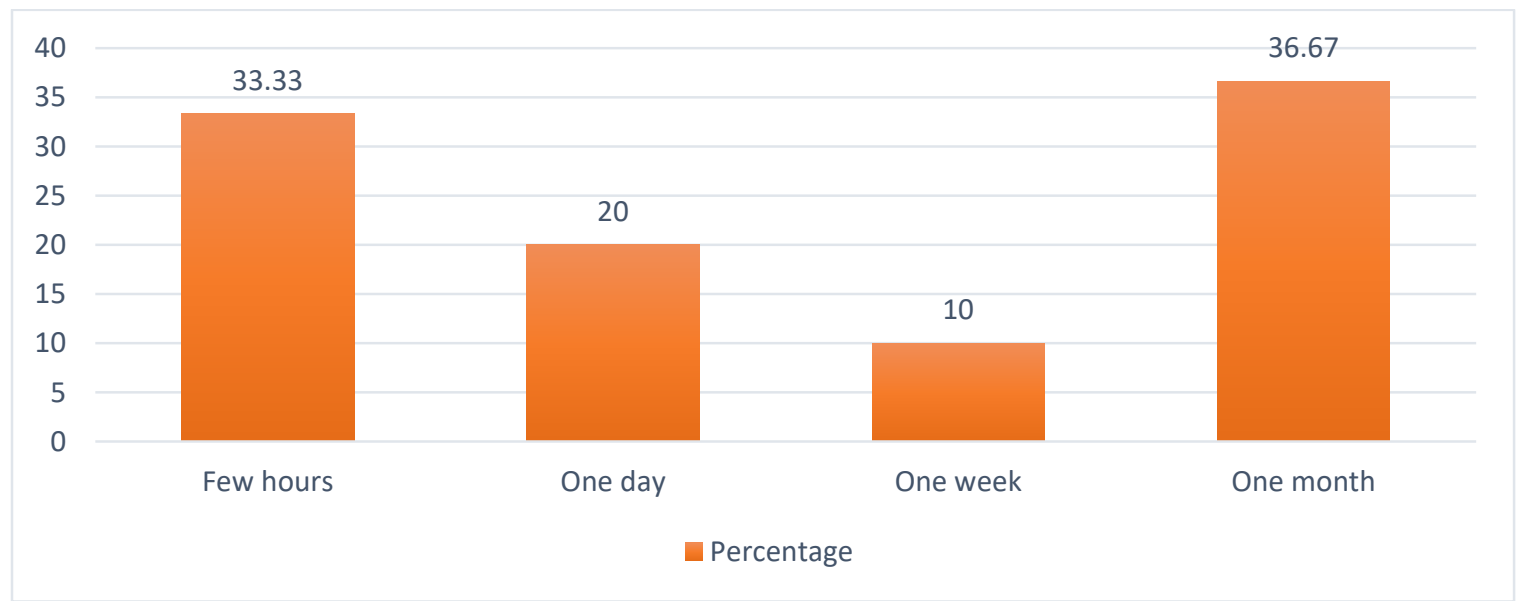

Figure 4.12: Input of advertisement

It is also found that the consumers with the age group of 29-39 years have the input of more than a month which was $20 \%$ while the age group of $40-50$ years have its input for a few hours which was $16.67 \%$ of the consumers as mentioned in the Annexure H. It shows that brand recognition and awareness through the advertisement is more effective to the age group of 29-39 years. Similarly, 30\% of the consumer with the occupation as the Business had few hours of input of an advertisement. Thus, the study suggests that the marketing tools shall be applied with respect to the socio-demographic characteristics to aware about the brands. 


\section{Conclusions}

The study shows that advertising is the key marketing strategy tool of the manufacturer where $43.33 \%$ of the consumer has positive impression when they see the advertisement in different medium; 43.33\%television being most attainable medium. It is found to be useful to recall and make the interest in the specific cement brand to the consumer which helps to recognize the brand name as there are several cement manufacturers throughout the country including the cement from India too. It helps the manufacturer to influence the consumers' preference and set in "Top of mind" when they have to choose the cement brands and can be attained best through different promotional tools.

The study shows that $36.67 \%$ and $23.33 \%$ of the total sample size of suppliers have received bonus coupons and credit period respectively. It can be analyzed that suppliers are influenced by bonus coupon as the promotional tool due to which they buy the cement brands from manufacturers. While $50 \%$ of total consumer have received credit period as an effective promotional tool from the supplier. From this, it can be analyzed that the credit period is the key marketing strategy that applies to the supplier due to which they can sell the cement to the end consumer in the credit with definite period. With this, both suppliers and consumers get the benefit of cash flow management as manufacturer applied 30 days of credit period while supplier applied 7 days of credit period to the end consumer creating the space in between to manage the cash flow for the supplier and consumer can purchase other important raw material during that period.

\section{References}

[1] Aaker, D. A. 1996, Building strong brand. New York: Free Press.

[2] Ajzen, I. and Fishbein, M. 1977, Attitude-Behaviour Relations: A Theoretical Analysis and Review of Empirical Research. Psychological Bulletin. In Solomon, M.R. 1995, Consumer Behaviour, 3rd ed., Prentice Hall.

[3] Alba, J.W. and Hutchinson, J.W. 1988, Dimensions of Consumer Expertise. Journal of Consumer Research

[4] Allen, C.T. and Madden, T.J. 1985, A Closer Look at Classical Conditioning. Journal of Consumer Research.

[5] AMA Task Force on the Development of Marketing Thought 1988, Developing, disseminating, and utilizing marketing knowledge. Journal of Marketing.

[6] Anderson, P.F. 1983, Marketing, scientific progress and scientific method. Journal of Marketing.

[7] Anderson, P.F. 1986, On method in consumer research: a critical relativist perspective. Journal of Consumer Research, Vol. 13.

[8] Babalola, Y. A. 2012, Impact of corporate social responsibility on firm's profitability in Nigeria. European Journal of Economics, Finance and Administrative Sciences.

[9] Bagozzi, R. P. 1975, Marketing as exchange. Journal of Marketing.

[10] Belk, R. W. 1988, Possessions and the Extended Self. Journal of Consumer Research.

[11] Belk, R.W. 1974, An Exploratory Assessment of Situational Effects in Buyer Behaviour. Journal of Marketing Research.

[12] Bettman, J.R. and Zins, M.A. 1977, Constructive Processes in Consumer Choice. Journal of Consumer Research.

[13] Boley, T. A. 2011, Effect of marketing strategies on consumer's satisfaction in Bolivia: A case for emerging firms. Journal of Marketing Management. 
[14] Braithwaite, A. 1983, Situations and social actions: Applications for marketing of recent theories in social psychology. Journal of Market Research Society.

[15] Bruner, G.C. 1990, Music, Mood, and Marketing. Journal of Marketing.

[16] Burke, P.J. and Franzoi, S.L. 1988, Studying Situations and Identities Using Experimental Sampling Methodology. American Sociological review 53, August, pp. 559-568. In Solomon, M.R. 1995, Consumer Behaviour, 3rd ed., Prentice Hall.

[17] Chai, L. G. 2009, A review of marketing mix: 4ps or more? International Journal of Marketing Studies.

[18] Chesbrough, H. W., and Appleyard, M. M. 2007, Open Innovation and Strategy. California Management Review.

[19] D. and Littler, D. 1998, Positioning Alternative Perspectives of Consumer Behaviour. Journal of Marketing Management.

[20] D.M. and Deshpande, R. 1989, Situational Ethnicity and Consumer Behaviour. Journal of Consumer Research.

[21] Dolak, D. 2003, Building a Strong Brand: Brands and Branding Basics. Accessed from www.davedolak.com/articles/dolak4.htm

[22] Donthu, N., \& Gilliland, D. 1996, Observations: The infomercial shopper. Journal of Advertising Research.

[23] Doyle, P. 2002, Marketing Management and Strategy, (3rd edition). Harlow: Pearson Education

[24] Ekinici, S. 2008, An examination of antecedents and consequences of customers satisfaction. In Crouch, G. I., Perdue, R. R. \& Uysal, M. consumer psychology of tourism, hospitality and leisure. Cambridge: CABI Publishing.

[25] Engel, James F., Roger D., Blackwell and Paul W. Miniard 1993, Consumer Behavior. Orlando, Fl: The Dryden Press

[26] Eysenck H. J. and Eysenck S. B. G. 1975, The Eysenck Personality Questionnaire. London: Hodder \& Stoughton.

[27] Farris, P. W., Neil, T. B., Philip, E. P. \& David, J. R. 2010, Marketing metrics: The definitive guide to measuring marketing performance. New Jersey: Pearson Education Inc.

[28] Feinberg, R.A. 1986, Credit Cards as Spending Facilitating Stimuli: A Conditioning Interpretation.

[29] Feldman, L.P. and Hornik J. 1981, The use of time: An integrated conceptual model. Journal of Consumer Research.

[30] Firat Fuat A., Dholakia N., Venkatesh A.1995, Marketing in a postmodern world. European Journal of Marketing, Vol. 29 Issue: 1.

[31] Holbrook, Morris B. and Elizabeth C., Hirschman.1982, The experiential aspects of consumption: Consumer fantasies, feelings, and fun. Journal of Consumer Research.

[32] Indian Bureau of Standards. 1976, Specification for Ordinary Portland Cement.

[33] Indian Bureau of Standards. 1978, Specification for Ordinary Portland Cement.

[34] Indian Bureau of Standards.1989, Specification for Ordinary Portland Cement.

[35] Kannan, L. 2009, Study of Consumer Behaviour in Cement Decision making.

[36] Kathmandu-Valley. 2017, Accessed from www.kathmandu-valley-temples.com on June, 2017.

[37] Keller, Kevin L. 1993, Conceptualizing, Measuring, and Managing Customer-Based Brand Equity. Journal of Marketing.

[38] Kotler, P. 2000, Marketing Management. The Millennium Education.

[39] Kotler, P. 2003, Marketing Management. Prentice Hall 11th European edition.

[40] Kotler, P. and Wong, Veronica and Saunders, John and Armstrong, Gary. 2005, Principles of marketing. 4th edition, Pearson Education Limited.

[41] Kurtz, L D. 2012, Kurtz \& Boone Principles of Contemporary Marketing.

[42] Lewis, A., Webley, P. and Furnam, A. 1995, The New Economic Mind.2nd Ed. Prentice Hall. 
[43] Mahasenan, Natesan, Smith.S, Humphreys K and Y. Kaya. 2003, The Cement Industry and Global Climate Change: Current and Potential Future Cement Industry.

[44] Marsden D. and Littler D.1998, Exploring consumer product construct systems with the repertory grid technique. Qualitative Market Research: An International Journal.

[45] Moller, K. 2006, The marketing mix revisited: Towards the 21st Century marketing. Journal of Marketing Management.

[46] Mishra, A. K., \& Jha, A. (2019). Assessment of Structure of Credit Policy and Sales Trend of Sarbottam Cement. Journal of Advanced Research in Business Law \& Technology Management, 2(1), 14-20.

[47] Mishra, A. K., \& Jha, A. (2019). Quality Assessment of Sarbottam Cement of Nepal. International Journal of Operations Management and Services, 9(1), 1-22.

[48] Mishra, A. K., \& Chaudhary, E. U. (2018). Cost effectiveness assessment of different nepalese cement brands for selected sites of supermarket. Journal of Advanced Research in Construction \& Urban Architecture, 3(3), 12-33.

[49] Mishra, A. K., \& Chaudhary, E. U. (2018). Assessment of cement handling behaviour for selected construction sites of bhatbhateni supermarket. Journal of Advanced Research in Construction \& Urban Architecture, 3(3), 1-11.

[50] Mishra A.K., and Sharestha B., 2019 Assessment of Consumer Influencing Factor in Decision Making for Selecting Cement BrandsSouth Asian Res J Bus Manag; Vol-1, Iss- 3 (Oct-Nov, 2019): 91-105 DOI:10.36346/SARJBM.2019.v01i03.002

[51] Morrison PD., Roberts JH. and Hippel Von E. 2000, Determinants of user innovation and innovation sharing in a local market. Management Science.

[52] Pachauri, M. 2001, The Marketing Review.

[53] Peter, J. Paul and Walter R. Nord 1982, A Clarification and Extension of Operant Conditioning Principles in Marketing. Journal of Marketing.

[54] Preston, H. 2012, Marketing strategies examples. Accessed from www.ehow.org.

[55] Piirto, R. 1991, Beyond Mind Games: The Marketing Power of Psychographics.

[56] Popvic, D. 2006, Modeling the marketing of high-tech startups. Journal of Targeting Measurement and Analysis for Marketing.

[57] Rosenberg, Milton J. 1956, Cognitive structure and attitudinal affect. Journal of Abnormal and Social Psychology.

[58] Rossiter JR \& Percy L.1987, Advertising and Promotion Management. Singapore: McGraw-Hill.

[59] Salah, B. 2017, Concrete Technology: Chapter 1.

[60] Scrizzi, M. 2007, Punk marketing. Journal of Consumer Marketing.

[61] Schmit, B. 1999, Experiential Marketing. Accessed from www.doi.org.

[62] Shaw, E. 2012, Marketing strategy: From the origin of the concept to the development of conceptual framework. Journal of Historical Research in Marketing.

[63] Sheth, J.N. 1992, Acrimony in the ivory tower: A restrospective on consumer research. Journal of the Academy of Marketing Science.

[64] Slife, B.D. and Williams, R.N. 1995, What's Behind The Research? Discovering Hidden Assumptions in the Behavioural Sciences.

[65] Smith, A. 1776, An Inquiry into the Nature and Causes of the Wealth of Nations.

[66] Solomon, M.R. 1983, The World of Products as Social Stimuli: A Symbolic Interactionism Perspective. Journal of Consumer Research.

[67] Solomon, M.R. 1995, Consumer Behaviour.3rd Ed. Prentice Hall Stayman.

[68] Sternthal, B., and Craig, C. S. 1982, Consumer Behavior: An Information Processing Perspective. Prentice Hall.

[69] World Bank. 2016, Annual Report. Accessed from www.worldbank.org.

[70] World Business Council for Sustainable Development. 2002, Annual Report. Accessed from www.wbcsd.org 
[71] Worrell E, Price L, Martin N, Hendriks C and Meida, L.O. 2001, Carbon Dioxide Emissions from The Global Cement Industry. Annual Review of Energy and the Environment.

[72] Yamane, T. 1967, Statistics, An Introductory Analysis, 2nd Ed. New York: Harper and Row.

[73] Youjae, Y. 2010, The determinants of consumer satisfaction: The moderating role of ambiguity. Journal of Consumer Research.

[74] Zila, D. 2012, Critical review of consumer satisfaction. American Marketing Association

*Corresponding author.

E-mail address: anjaymishra2000@gmail.com 